\title{
SAUDAÇÃO PROFERIDA PELO PROFESSOR FÁBIO NUSDEO AO NOVO TITULAR, PROFESSOR GUIDO FERNANDO SILVA SOARES
}

As Arcadas de São Francisco vivem esta noite um momento exponencial. Denso pelo significado e forte pelo sentimento.

Engalanadas com sóbria pompa acadêmica acolhem anelantes dois novos professores titulares: o professor Hermes Marcelo Huck na disciplina de Legislação Tributária abrangida pelo Departamento de Direito EconômicoFinanceiro, do qual tenho a honra de estar presentemente na chefia, e também em nome de todos os seus demais componentes, com especial júbilo dou, desde logo, as mais efusivas boas-vindas a tão caro amigo que ora nele ingressa.

O outro ilustre titular é Vossa Excelência, professor Guido Fernando Silva Soares, como novo professor pleno de Direito Internacional Público, cabendome, por honrosa deferência do nosso querido diretor, professor Álvaro Villaça Azevedo, vir-lhe abrir, de par em par, as portas do órgão máximo da Faculdade de Direito da Universidade de São Paulo: a sua Congregação, para que nela assuma o seu lugar - mais do que merecido - de membro nato, efetivo, vitalício.

Como a Academia, esta cerimônia é também velha e sempre nova.

Vetusta na forma, única na substância, esplendorosa em si própria; sempre renovada porque a cada vez se diferencia pela personalidade de quem lhe adentra o recinto. E esta personalidade será sempre, como o é neste caso, "jovem, terça e louçã", porque os espíritos velhos, encolhidos e ensimesmados não se abalançam a se apresentarem perante o pretório acadêmico do Largo de São Francisco. Nem suportariam as agruras de uma carreira exigente e penosa, mas estimulante e porque não dizer gloriosa, como a sua - professor Guido Fernando Silva Soares - que ora a justo título enaltecemos.

Mas estaríamos aqui apenas para enaltecer? Isto já seria muito e certamente necessário. Mas o sentido último desta cerimônia acadêmica transcende a mera louvação, por mais sólidas que sejam as suas bases.

Na realidade, a recepção ao novo membro pleno sempre integrou a vida das academias. E esta Casa desde o início se viu, um pouco, como Academia, sendo assim conhecida em tempos de antanho, muito embora tal designação jamais constasse de qualquer diploma legal. 
O toque acadêmico sempre pareceu repousar no sentido comunitário de tais instituições, desde o lendário Jardim de Academus com o seu ensino peripatético, passando por Bologna, Paris, Oxford e a nossa ancestral Coimbra, para chegar às já um pouco mais modernas academias de Cosimo da Medici em Florença e a de Richilieu em Paris, quando a oficialização de cunho estatal passa a predominar, mas sem lhes infirmar a índole comunitária, marca obrigatória de todos quantos pretendem dedicar suas vidas ao saber.

Numa sociedade polimorfa e difusa como aquela em que vivemos, é, pois, de se indagar do porquê mais profundo para uma ocasião como esta, por nós todos vivida com tanto júbilo e transporte de alma.

O professor recebido e bem-vindo não é mais como, até relativamente pouco tempo, um estranho que se lançava a um concurso sem prévia carreira. Pelo contrário, veio galgando, degrau a degrau, todos os lances da vida universitária mercê de renhidos concursos de provas e títulos que esta Casa, contrariando a maré facilitária de outras instituições brasileiras timbra em manter, exigindo, inclusive, a "obra prima" do mestre: a sua tese de titularidade.

Essa sucessão de provas e o desafio diuturno do ensino acabam por plasmar nos que por eles passaram o verdadeiro espírito universitário e, por via de conseqüência, um sentir comunitário, advindo da consciência do caminho percorrido, mas sobretudo da missão ainda a desempenhar. Por conseguinte, no seu âmago, o sentido lídimo da presente cerimônia é o de obter do recepcionado um pronunciamento solene, uma profissão de fé destinada a guiá-lo pelo tempo - que todos desejamos longo - durante o qual, ele estará a ensinar, a pesquisar, a produzir em prol da Ciência e, conseqüentemente, da Humanidade.

Se é justo louvarmos o vitorioso de tantas etapas não menos impositivo é inquiri-lo sobre a que veio, como vislumbra a sua missão a ser conduzida agora do píncaro da posição conquistada. Nisso tudo há pelo menos duas profissões de fé. Fé dos que o recebem e fé daquele que tendo atingido o topo descortina o imenso plano a ser palmilhado e vivificado com sua experiência.

Receba a nossa fé, professor Guido Fernando Silva Soares. Vossa Excelência é dela muito merecedor não apenas pela galharda e brilhante carreira acadêmica, mas pela sua vida, vivida com dignidade e altruísmo em todos os seus momentos e instâncias, mesmo nos mais adversos. 
Na vida universitária e na vida da arte - sobretudo a musical - onde se distingue como exímio pianista; na vida diplomática que o seu espírito aberto e universalista o levou a abraçar. E onde pagou um alto preço pela sua coerência, pela sua dignidade e pelo seu acendrado amor ao dever e ao próximo.

É de todos conhecido o episódio pouco edificante para a diplomacia brasileira dos anos de chumbo, quando Vossa Excelência, então Secretário da Embaixada em Montevidéu, no estrito cumprimento do seu dever funcional, procurava atender e dar assistência a cidadãos brasileiros fugidos ou exilados - não importa - na capital uruguaia. Com isso atraiu a desconfiança do chamado "sistema" que na sua paranóia maniqueísta o via como um aliado do Mal, em oposição ao Bem, representado por ele "sistema" Daí as pressões para a sua renúncia e demissão.

Consumada tal demissão, de regresso ao Brasil, vem-se abrigar no seio sempre generoso desta velha e sempre nova Academia, onde é acolhido como filho dileto, dedicando-se, então, por diversos anos ao ensino e à pesquisa, com ardor, proficiência e humildade, cujos frutos opimos nós todos colhemos ao perlustar a sua obra, farta, profunda e pioneira, onde sobressaem títulos como: Salvaguardas nos Acordos Nucleares; Concessões de Exploração de Petróleo e Arbitragem Internacional; Imunidades de Jurisdição; Órgãos de Solução Extra-Judicial de Litigios; A Guerra Nuclear e o Direito; Contratos Internacionais de Comércio; Ambiente e Poluição Internacional e Direito Internacional Econômico.

Passaram-se, assim, os anos e atenuaram-se os radicalismos. A Casa de Rio Branco fez-lhe finalmente justiça reintegrando-o com todas as honras nos seus quadros para completar a brilhante carreira insolitamente interrompida, a culminar agora na posição de Ministro Conselheiro, da qual vem de se aposentar.

É com todos esses lauréis que Vossa Excelência, senhor professor titular, com o cabedal da experiência vivida no Brasil e no Exterior, com a plena consciência do dever cumprido em duas dignificantes carreiras - a diplomática e a universitária - mas, sobretudo, com a plena maturidade do seu espírito de humanista, assume agora na Congregação das Arcadas o posto a si especialmente talhado e afeiçoado: o de Titular de Direito Internacional Público. Ela não é um ponto de chegada, mas uma base de partida, ou melhor, de lançamento: lançamento para vôos cada vez mais altos não pela grandiloqüência dos ouropéis mas pelo constante, humilde e pertinaz rasgar dos novos horizontes do Direito Internacional, refúgio e 
esperança para o complexo dos direitos das gentes nesta ameaçadora, vibrante, mas também estimulante passagem para o novo milênio.

Que Deus o ilumine para a plenitude de sua missão.

São Paulo, junho de 1998. 